\title{
Optimalisasi Produk Emping Melinjo Guna Meningkatkan Nilai Tambah Bagi Masyarakat Kampung Cipanas Baru Desa Mancak Kabupaten Serang
}

\author{
“Optimizing Emping Melinjo Products to Increase Added Value for the Community of \\ Cipanas Baru Village, Mancak Serang" \\ Deni Sunaryo \\ Jurusan Manajemen Fakultas Ekonomi dan Bisnis Universitas Serang Raya \\ Email: denisunaryomm@gmail.com
}

\begin{abstract}
Abstrak
Penduduk Desa Mancak berjumlah 4278 jiwa, yang terdiri dari laki-laki 2168 jiwa dan perempuan 2110 jiwa, umumnya penduduk bekerja di ladang dan buruh kasar serta pedagang, sedangkan untuk Ibu rumah tangga hanya membantu pekerjaan rumah.

Luas Wilayah Desa Mancak 538.8 Ha dimana 64\% nya adalah Pertanian dan perkebunan. Hasil utama alam dan ciri khas dari Desa Mancak adalah melinjo, kelapa dan bambu, pada pengabdian ini difokuskan pada optimalisasi pengembangan produk hasil olahan emping melinjo disebabkan sangat potensial untuk ditingkatkan nilai daya guna serta nilai tambah atas produk hasil olahan melinjo tersebut sehingga hasil produk olahan tidak semata hanya emping melinjo alami saja, namun mempunyai alternatif variasi produk hasil olahan emping melinjo dengan berbagai aneka macam tersebut. Tujuan pengabdian yang dilakukan adalah menjalankan fungsi Tridarma Perguruan Tinggi, metode yang digunakan adalah memberikan supervisi dan tahapan dalam membuat inovasi produk sampai dengan siap jual sesuai dengan beberapa segment pasar dan pada penelitian ini difokuskan pada satu kampung yaitu kampung Cipanas Baru Desa Mancak Kecamatan Mancak Kabupaten Serang. Hasil pengabdian ini memberikan manfaat bagi penduduk di Kampung Cipanas baru Desa Mancak guna meningkatakan nilai tambah produk dan menambah pendapatan bagi keluarga. Dan bagi pengabdi dalam menjalankan fungsi Tridarma Perguruan Tinggi.
\end{abstract}

Abstract

The population of the village of Mancak is 4278 people, consisting of 2168 men and 2110 women, generally the population works in fields and unskilled laborers and traders, while for housewives only helps with homework. The area of Mancak Village is 538.8 $\mathrm{Ha}$, of which $64 \%$ is Agriculture and plantations. The main results of nature and distinctive features of Mancak Village are melinjo, coconut and bamboo. The service is focused on optimizing the development of processed products from melinjo chips due to the potential to increase the value of usability and the added value of melinjo processed products so that processed products are not only natural crackers are only natural, but have an alternative variety of products processed by melinjo chips with various kinds of them. The purpose of service is to carry out the Tridarma function of Higher Education, the method used is to provide supervision and stages in making product innovations up to ready to sell according to several market segments and in this study focused on one village namely Cipanas Baru village Mancak Village Mancak District Serang District. The results of this service provided benefits for residents in the new Cipanas village in Mancak Village to increase value added products and increase income for the family. And for servants in carrying out the functions of the Tridarma of Higher Education.

Kata Kunci: Optimalisasi, Inovasi, Nilai Tambah, Tridarma. 


\section{PENDAHULUAN}

Desa Mancak, Kec. Mancak, Kab. Serang merupakan desa dengan kontur keagamaan dan memiliki keadaan serta budaya yang menarik, terdiri dari $17 \mathrm{RT}$ dan $4 \mathrm{RW}$, dan juga terdiri dari beberapa kampung, yaitu, Kp. Libadak, Kp. Saraga, Kp. Cipanas Baru, Kp. Keresek dan Kp. Citundun dll, desa Mancak dengan segudang potensi nya di setiap kampung, namun mayoritas Masyarakat di desa Mancak adalah petani dan Pedagang namun di desa Mancak untuk potensi yang diberdayakan tidak banyak karena kurangnya kemauan dan usaha dari Masyarakat dan pemerintah desa untuk membimbing masyarakat dalam hal memberdayakan hasil alam supaya dijadikan nilai Ekonomi Kreatif atau potensi yang di miliki oleh desa Mancak karena desa hanya melihat kepada mayoritas Masyarakat nya adalah petani dan Buruh sehingga hasil alam yang lain yang ada di desa Mancak selain padi kurang di perhatikan dengan baik contohnya pada Kp. Cipanas baru hasil alam seperti Kelapa yang sangat melimpah tidak di perhatikan dengan baik seandainya saja jika Kelapa yang di berdayakan dengan baik menjadi produk ekonomi Kreatif bisa menjadi ikon yang sangat terkenal di desa Mancak namun sayangnya kurangnya kesadaran dan kemauan Masyarakat, serta dibantu pemerintah desa untuk memberdayakan hasil alam yang berupa Kelapa. Tidak hanya Kelapa yang menjadi potensi yang ada di Kp. Cipanas baru, ada juga melinjo sebagai penghasilan harian masyarakat menjadikan kurang nya potesi alam yang diberdayakan di desa Mancak untuk saat ini kelapa dengan mengambil buahnya dan dijual dan biji melinjo hanya dipisahkan dari bijinya dan dijual begitu saja tanpa ada proses inovasi lebih lanjut untuk mengolah hasil alam atau melinjo tersebut. Di kampung-kampung yang lain di Desa Mancak melimpahnya hasil alam berupa melinjo dan kelapa sedangkan di kampung lain memiliki hasil alam yang berbeda-beda semacam coklat padi dll. Contohnya di Kp. Cipanas baru, memiliki hasil alam berupa kelapa dan melinjo, singkongnya. Namun, tanaman coklat tidak banyak orang yang menanam. hanya beberapa saja namun lumayan banyak pohon coklat yang ada di Kp. Cipanas baru. Lain hal nya, dengan singkong di Kp. Cipanas baru sudah pernah di berdayakan dalam bentuk kripik singkong hanya saja sulitnya segi pemasaran kripik singkong mulai adanya kemunduran dalam pengolahan kripik singkong sehingga saat ini pengolahaan kripik singkong hanya untuk di kampung tersebut bahkan produk rumahan sendiri. Dalam pengabdian ini ingin kembali memunculkan produk yang dulu nya menjadi produk unggulan di desa mancak dan Kp. Cipanas baru sehingga mampu meningkatkan pendapatan masyarakat selain dari perkebunan dan buruh.

Sedangkan di Kp Cipanas Baru Desa Mancak dan Kp. Curug barang masih kental dengan usaha rumahan seperti usaha pribadi ada yang menjual parfum dan usaha fotocopyan juga warung warung kecil namun hasil alam yang ada di Kp. Cipanas Baru Desa Mancak dan parigi belum terlihat karena budaya yang ada di kedua desa ini sudah terlihat sudah sedikit kekotaan sehingga kurangnya kesadaran akan penting nya mengolah hasil alam yang ada, kebanyakan di kedua kampung ini Masyarakatnya bekerja di luar atau sebagian ada yang buruh tani dan petani, mayoritas masih mengandalkan pada hasil pertaniannya. 


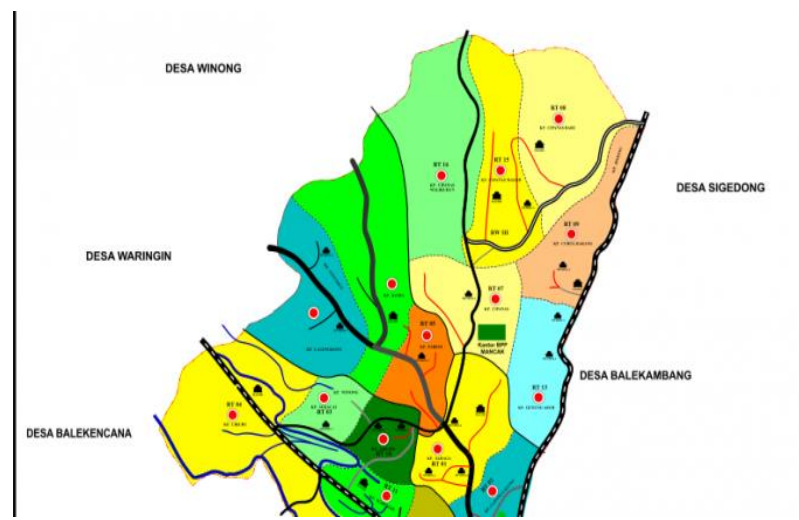

Gambar 1. Peta Desa Mancak Kecamatan Mancak Kabupaten Serang Banten

Itulah sedikit nya keadaan alam dan potensi alam desa Mancak yang ada masih banyaknya potensi alam yang belum di berdayakan oleh desa dan masih kurangnya pengetahuan dan kemauan masyarakat di desa untuk memberdayakan hasil alam yang ada di sekitarnya mungkin karena terbatasnya pengetahuan, waktu keadaan di desa mancak dari rumah kerumah bahkan jarak kampung ke kampung tidak terlalu dekat maka pengabdian ini hanya memberikan supervisi dan tahapan pengolahan emping melinjo sehingga siap untuk dijual kepasar sesuai dengan trend pasar yang sedang dibutuhkan oleh konsumen berikut dengan desain dan metode kemasan dalam mengolah dan berinovasi dengan hasil alam yang ada sehingga mayorias masyarakat dapat mengoptimalkan hasil dari perkebunan dan pertaniannya.

Banyak sekali yang di hadapi oleh masyarakat yang ada di desa Mancak salah satu nya adalah masih kurangnya kesadaran dan kemauan masyarakatnya serta masih selalu mengandalkan pendapatan dari Perkebunan dan pertanian, juga masih berfikir keuntungan pribadi saja di banding membuat kelompok-kelompok usaha kecil guna meningkatkan pendapatan, gerakan pemuda yang terlihat jika ada momen yang penting saja namun keagamaan seperti pengajian kurang berpartisipasi hanya orang tua saja, bahkan karang taruna yang menjadi organisasi sentral ditengah-tengah masyarakat masih adanya gap atau jarak antara Masyarakat sehingga kurangnya komunikasi dan koordinasi dari masing-masing Masyarakat, tidak adanya tempat pembuangan sampah umum sehingga sampah yang berasal dari rumah tangga hanya dibakar dan dibuang ke lahan dekat rumah yang kosong.

Tidak adanya usaha dari pemerintah desa untuk melakukan pelatihan dan penambahan wawasan akan pentingnya mengelola hasil alam yang ada selain dari perkebunan, banyak lahan yang tidak terpakai tidak di manfaatkan dengan baik sehingga, kurangnya aktivitas pemuda di desa Mancak, lebih terlihat aktivitas ibu ibu dan anakanaknya, kegiatan gotong royong yang sulit berjalan di desa Mancak karena para bapak-bapak dan pemudanya kurang aktif terkait kegiatan sosial yang seperti itu hanya itu saja sepertinya permasalahan yang ada Masyarakat yang ada di desa Mancak, selebihnya adalah yang paling sulit itu menanamkan pola fikir dan mengarahkan kepada masyarakat terkait pentingnya memaksimalkan potensi alam yang ada di sekitar mereka agar hasil alam yang di olah dan di berdayakan dengan baik dapat membantu sedikitnya keuangan Masyarakat yang ada di desa Mancak selain pendapatan utama mereka dari buruh tani dan petani bagi yang memiliki sawah karena jikalau mengharapkan dan bertumpu pada penghasilan kepala keluarga dari bertani serta buruh tani masih kurang untuk meningkatkan kesejahteraan masyarakat yang ada di Desa Mancak.

Tujuan pengabdian adalah menjalankan Tridarma Perguruan Tinggi bagi pengabdi sehingga 
mempunyai dampak pada peningkatan sumber daya masyarakat baik secara fisik maupun non fisik.

Solusi yang ditawarkan pada masyarakat untuk pengabdian ini dengan cara :

- Memberikan penyuluhan dan pendampingan pada proses peningkatan nilai tambah bagi masyarakat Kampung Cipanas Baru.

- Membuka diskusi dengan mitra atas kebutuhan akan produk yang diminati oleh pasar.

- Membantu pendampingan dalam pola pemasaran.

Dalam pengabdian ini kita dapat mengacu terhadap beberapa teori yang sudah dikemukan diantaranya adalah Optimalisasi, dimana optimalisasi merupakan salah satu teknik dan cara untuk mendayagunakan sumber-sumber daya agar lebih efektif dan efesien serta mempunyai dampak yang membangun. Menurut Depdikbud (1995, h. 628) Optimalisasi berasal dari kata optimal berarti terbaik, tertinggi, sedangkan optimalisasi berarti suatu proses meninggikan atau meningkatkan ketercapaian dari tujuan yang diharapkan sesuai dengan kriteria yang telah di tetapkan.

Reka baru atau inovasi (bahasa Inggris : innovation) dapat diartikan sebagai proses dan/atau hasil pengembangan pemanfaatan/ mobilisasi pengetahuan, keterampilan (termasuk keterampilan teknologis) dan pengalaman untuk menciptakan atau memperbaiki produk (barang dan/atau jasa), proses, dan/atau sistem yang baru, yang memberikan nilai yang berarti atau secara signifikan (terutama ekonomi dan sosial). Reka baru sebagai suatu "objek" juga memiliki arti sebagai suatu produk atau praktik baru yang tersedia bagi aplikasi, umumnya dalam suatu konteks komersial.
Biasanya, beragam tingkat kebaruannya dapat dibedakan, bergantung pada konteksnya: suatu inovasi dapat bersifat baru bagi suatu perusahaan (atau agen/aktor), baru bagi pasar, atau negara atau daerah, atau baru secara sejagat. Sementara itu, reka baru sebagai suatu "kegiatan" merupakan proses penciptaan reka baru, seringkali diidentifikasi dengan komersialisasi suatu reka cipta.

Nilai tambah menurut Haller dan Stolowy (1995) Value Added (VA) atau Nilai Tambah adalah pengukuran performance entitas ekonomi yang memiliki sejarah panjang pada aplikasinya dalam ilmu ekonomi. Arti nilai tambah dapat diartikan juga sebagai perbedaan antara nilai dari output suatu perusahaan atau suatu industri, yaitu total pendapatan yang diterima dari penjualan output tersebut, dan biaya masukan dari bahan-bahan mentah, komponen-komponen atau jasa-jasa yang dibeli untuk memproduksi komponen tersebut. Ada juga yang mengartikan nilai tambah adalah nilai yang ditambahkan oleh suatu perusahaan ke bahanbahan dan jasa-jasa yang dibelinya melalui produksi dan usaha-usaha pemasarannya. Nilai tambah diketahui dengan melihat selisih antara nilai output dengan nilai input suatu industri.

Kegiatan pengabdian ini juga diharapkan membawa dampak dan manfaat bagi masyarakat untuk meningkatakan dan mengoptimalisasikan nilai tambah dari hasil produksi sehingga para konsumen lebih tertarik untuk membelinya atas produk yang dihasilkan dengan berbagai inovasi.

\section{METODE PELAKSANAAN}

Tempat pengabdian dilaksanakan di Kampung Cipanas baru Desa Mancak Kecamatan Mancak Kabupaten Serang Provinsi Banten. Waktu pelaksanaan dari bulan Juli sampai dengan Agustus tahun 2018 selama 5 hari.

Tabel-1 Waktu Kegiatan Pelaksanaan Pengabdian 


\begin{tabular}{|l|l|l|}
\hline No. & Hari Ke- & \multicolumn{1}{|c|}{ Kegiatan } \\
\hline 1 & Hari Ke-1 & Penyuluhan materi \& diskusi \\
\hline 2 & Hari Ke-2 & Pengolahan emping melinjo \\
\hline 3 & Hari Ke-3 & $\begin{array}{l}\text { Pengolahan emping melinjo } \\
\text { dengan aneka rasa }\end{array}$ \\
\hline 4 & Hari Ke-4 & $\begin{array}{l}\text { Penyuluhan Pemasaran dan } \\
\text { Praktek Pendampingan } \\
\text { Pengemasan produk }\end{array}$ \\
\hline 5 & Hari Ke-5 & Pendampingan kemitraan \\
\hline
\end{tabular}

mengikuti kegiatan pengabdian ini sebanyak 24 jiwa yang kesemuanya berjenis kelamin perempuan dan laki laki.

Metode yang dilakukan dengan cara beberapa pendekatan penyuluhan dan penyampaian materi serta pendampingan praktek dan pendampingan pemasaran kepada mitra.

Indikator keberhasilan pada pelaksanaan ini adalah

- Adanya peserta yang aktif

- Adanya kegiatan proses pembuatan produk sebelum dan sesudah inovasi

- Adanya penerimaan pasar dan respek pasar terhadap produk

\section{HASIL DAN PEMBAHASAN}

Pada kegiatan pengabdian ini para peserta sangat aktif untuk memberikan potensi dan informasi atas kemampuannya dalam bekerjasama untuk kegiatan pengabdian ini, sehingga komunikasi dalam penyuluhan penyampaian materi tidak kaku dan mudah untuk dipahami. Sistem penyampaian materi juga dilakukan secara fleksibel dimana ada ruang untuk melakukan penyampaian informasi maka disanalah materi diberikan kepada peserta

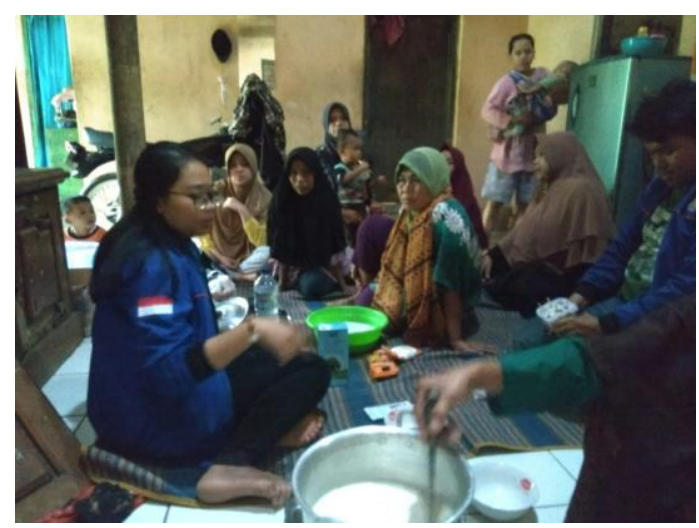

Gambar 2. Pelatihan pengolahan bumbu untuk emping melinjo bagian dari tahapan proses produksi

Proses produksi emping di kampung cipanas baru sangatlah berlimpah sehingga peserta diajarkan secara inovatif dalam mengembakan produk turunan dari emping, salah satunya adalah pembuatan emping melinjo citarasa, dimana emping melinjo ini diharapkan mempunyai kualitas rasa jika dilakukan penggorengan. Proses pertamanya adalah pembuatan emping melinjo setelah disangrai maka emping melinjo siap ditumbuk dengan ditambahkan bumbu-bumbu rempah alami yang tersedia di pekarangan atau kebunkebun warga salah satu bumbu dapur. Setelah itu dilakukan proses penjemuran.

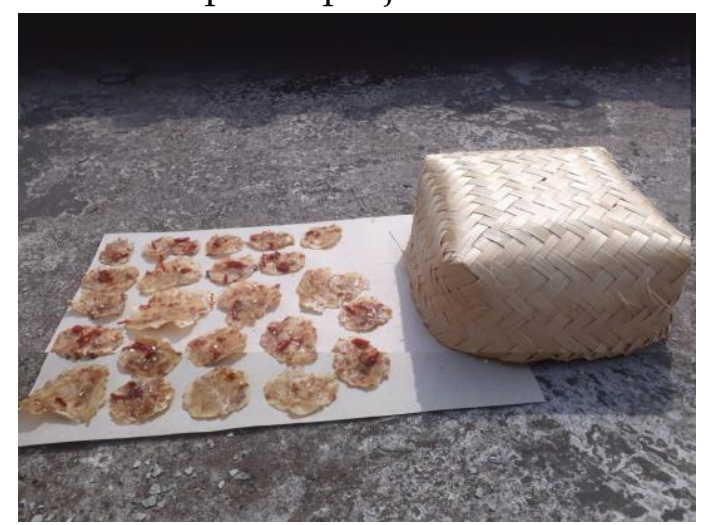

Gambar 3. Pelatihan penjemuran emping melinjo bagian dari tahapan proses produksi

Pengemasan produk dan merk terlebih dahulu meminta masukan kepada peserta sehingga dirumuskanlah merk yang sedang trend dan mempunyai nilai tradinasional saat ini yaitu "barbaran emping" yang mempunyai arti seadanya dan berasa. Untuk pengemasan 
juga dengan mengunakan plastik transparan sehingga konsumen dapat lebih tertarik untuk membelinya.

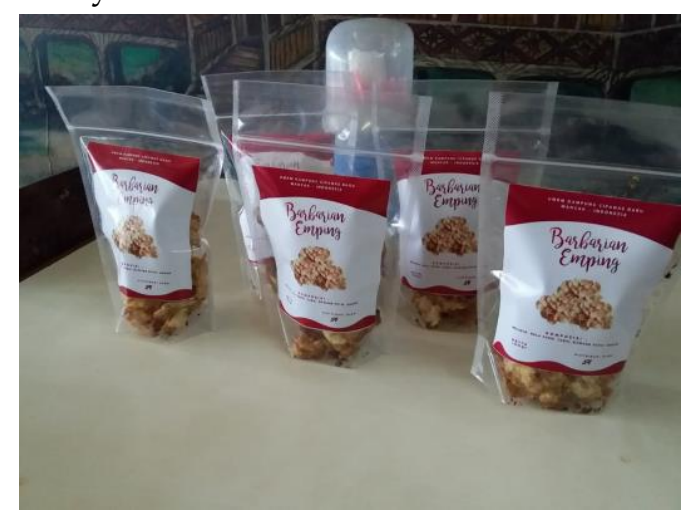

Gambar 4. Pelatihan Pengemasan emping melinjo bagian dari tahapan proses produksi

Program kemitraan merupakan salah satu tahapan terakhir dari kegiatan Pengabdian ini dan bagian terpenting dalam menentukan indikator keberhasilan, dimana salah satu manfaat indikator ini adalah menciptakan tambahan nilai pendapatan bagi keluarga sehingga mempunyai dampak luas terhadap masyarakat sekitarnya. Dengan adanya program kemitraan dalam pemasaran ini juga memberikan stimulus dan rangsangan bagi pelaku usaha lain dalam membuat nilai-nilai inovasi yang lebih, sehingga rantai pasok dari pemilik pohon emping melinjo sampai dengan pengolahan emping melinjo serta penjualan emping melinjo lebih berkelanjutan dan mempunyai umur yang panjang.

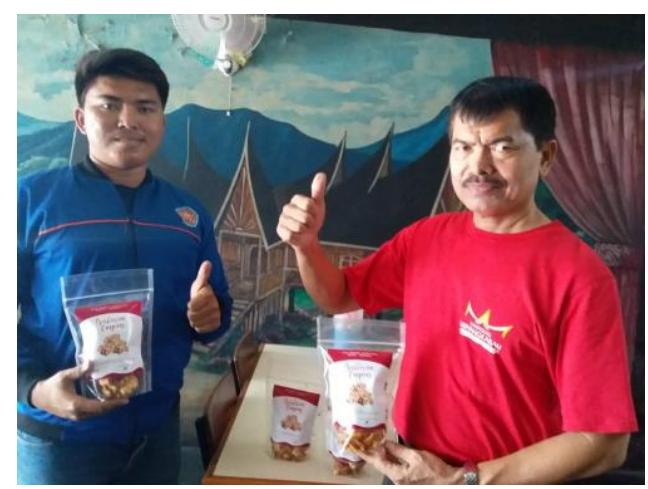

Gambar 5. Pendampingan Kerjasama

Kemitraan dalam rangka Pemasaran Produk
Ucapkan terima kasih kepada

- Rektor dan Wakil Rektor Universitas Serang Raya

- Dekan dan Wakil Dekan Fakultas Ekonomi dan Bisnis Universitas Serang Raya

- Kaprodi Manajemen Fakultas Ekonomi dan Bisnis Universitas Serang Raya

- Kabiro LPPM Universitas Serang Raya

- Kepala Desa Mancak dan Jajarannya

- Masyarakat Kampung Cipanas Baru Desa Mancak Kecamatan Mancak Kabupaten Serang

\section{KESIMPULAN DAN SARAN}

\section{Kesimpulan}

Program kegiatan pengabdian ini mempunyai manfaat dan dampak yang lebih luas dalam peningkatan nilai tambah bagi masyarakat khususnya nilai tambah pendapatan masyarakat dan optimalisasi waktu kegiatan masyarakat. Alternatif dan inovasi atas produk merupakan bagian dari pengembangan produk sehingga pembeli dan calon pembeli tidak jenuh. Kemitraan juga hal terpenting karena bagian akhir dari pola nilai tambah, dan masyarakat harus mampu dan mau untuk menerima masukan dari mitra.

\section{Saran}

Pengabdian atas Optimalisasi Produk Emping Melinjo Guna Meningkatkan Nilai Tambah Bagi Masyarakat Kampung Cipanas Baru Desa Mancak Kabupaten Serang harus terus dilaksanakan khususnya ke kampung kampung sekitar masyarakat cipanas baru sehingga dapat tercipta sel kewirausahaan yang lebih kompetitif.

Dukungan pemerintah baik kecamatan maupun kabupaten melalui Satuan Kerja Perangkat Daerah (SKPD) yang berkompeten dalam memberikan penyuluhan pendampingan sehingga lebih termonitor dalam hal pengelolaan potensi dan peluang pemasaran.

\section{Ucapan Terima Kasih}




\section{DAFTAR REFERENSI}

Sutrisno Noer. 2004. Sari Hasil Penelitian Hasil Pertanian. Pusat Penelitian Hasil Pertanian. Bogor

Tambunan, T. 2000. Perkembangan Industri Skala Kecil Di Indonesia. Jakarta: PT. Mutiara Sumber Widya.

Tarsis Tarmudji. 1999. Prinsip-prinsip Wirausaha. Yogyakarta: Liberty. 